\title{
Leucocytozoon toddi and Haemoproteus tinnunculi (Protozoa: Haemosporina) in the Chimango Caracara (Milvago chimango) in Southern Chile
}

\author{
Donald J Forrester $/{ }^{+}$, Garry W Foster, Joan L Morrison*
}

Department of Pathobiology, College of Veterinary Medicine, University of Florida, Gainesville, Florida 32611, USA *Department of Biology, Trinity College, Hartford, Connecticut, USA

Two species of blood protozoans were identified from blood smears collected from 15 specimens of the Chimango caracara (Milvago chimango) on Isla Grande de Chiloé in southern Chile. These included Leucocytozoon toddi in 13 birds, including all 5 of the 4-6 week old nestlings examined, and 8 of the subadults or adults. One of the nestlings also had a dual infection of L. toddi and Haemoproteus tinnunculi. These are the first reports of blood parasites from M. chimango.

Key words: Leucocytozoon toddi - Haemoproteus tinnunculi - Milvago chimango - chimango caracara - Chile

The chimango caracara (Milvago chimango) is a member of the Falconidae family and is common in southern South America (del Hoyo et al. 1994). It is a generalist predator and feeds on a variety of foods including carrion, human refuse, and a number of animals such as invertebrates, nestling birds, and small mammals (Yañez et al. 1982). With the exception of certain facets of its food habits and breeding biology, little is known about this Neotropical raptor (Fraga \& Salvador 1986, Morrison \& Phillips 2000). Published data on its parasites are limited to one paper on chewing lice (Tendeiro \& Mendes 1994) and one on parasitic helminths (Boero \& Led 1971). No information on blood parasites has been published. Herein we report information on blood parasites obtained while one of us (JLM) was studying the nesting habitat and success of $M$. chimango during two breeding seasons of this caracara in southern Chile.

\footnotetext{
This is Florida Agricultural Experiment Station Journal Series No. R-07880. Voucher blood films have been deposited in the Institute of Parasitology, Universidad Austral de Chile, Valdivia, Chile (IPUAT nos. 0271 and 0272) and the US National Parasite Collection, Beltsville, Maryland, USA (USNPC nos. 090867 and 090868). Financial support: The Committee for Research and Exploration of The National Geographic Society.

${ }^{+}$Corresponding author. Fax: 352-392-9704. E-mail: ForresterD@mail.vetmed.ufl.edu

Received 30 January 2001

Accepted 27 June 2001
}

Fifteen $M$. chimango, 5 nestlings (4-6 weeks of age) and 10 non-breeding subadults or breeding adults, were sampled. These birds were captured on private farms on the northeastern end of Isla Grande de Chiloé, located in Region X in southern Chile $\left(43^{\circ} 55^{\prime} \mathrm{S}, 73^{\circ} 35^{\prime} \mathrm{W}\right)$, during the months of November, December, and January of 1998-1999 (n $=13)$, and January of $2000(n=2)$. The sampling was done essentially at sea level. Additional details on the study area and capture methods are given by Morrison and Phillips (2000).

Thin blood films were made from peripheral blood, air dried, and subsequently fixed in absolute methanol and stained with Giemsa for $1 \mathrm{~h}$ at $\mathrm{pH}$ 7.0. Films were examined at $400 \mathrm{X}$ and $1,000 \mathrm{X}$ oil immersion to detect the presence of blood parasites. At least 10,000 red cells were examined on each slide.

Two species of blood protozoans were identified. Leucocytozoon toddi was found in 13 (87\%) birds, including all the nestlings and 8 of the subadults or adults. One nestling had a dual infection of L. toddi and Haemoproteus tinnunculi.

Greiner and Kocan (1977) studied the various species of Leucocytozoon reported from falconiforms and determined that they are all synonyms of $L$. toddi. They further concluded that this species was highly variable morphologically and was the only leucocytozoid infecting falconiforms worldwide. In a subsequent publication, White et al. (1978) concluded that species of Leucocytozoon are transmitted to birds in the Neotropics, but at a very low rate and prevalence. Overall, they found that only $0.2 \%$ of 35,555 birds 
(955 species representing 80 families) were infected with a species of Leucocytozoon. This was in contrast to the findings of a similar study in North America where $17.7 \%$ of 57,026 birds ( 388 species of 55 families) had Leucocytozoon infections (Greiner et al. 1975). The reasons for the paucity of Leucocytozoon infections in South American birds are not clear, but White et al. (1978) suggested that it might be due to low sample sizes or to the absence or low prevalence of appropriate vectors. They further stated that all of the Leucocytozoon infections included in their analysis were from the montane regions where the necessary lotic habitats needed for the reproduction and development of simuliid vectors are more common. We are aware of only one previous record of a Leucocytozoon infection in a Neotropical raptor; that was in an American kestrel (Falco sparverius) in Mexico (Beltrán \& Pardiñas 1953). We know of no records of Leucocytozoon species in any of the nine species of caracaras that occur in South America. No leucocytozoid infections were identified in 223 crested caracaras (Caracara plancus) examined in southern Florida (Foster et al. 1998). The fact that all of the nestlings that we sampled on Isla Grande de Chiloé were infected by L. toddi is an indication that the simuliid vectors are breeding near the nesting sites of $M$. chimango and transmitting infections to them on the nest. Adult birds may also become infected on or near the nest. Although we did not sample for simuliid vectors, habitats on Chiloé provide suitable conditions for them. Perennial streams and rivers are common, as are swamps and ponds. The climate is temperate and humid; annual rainfall averages $2000 \mathrm{~mm}$.

Peirce et al. (1990) reviewed the haemoproteids of the Falconidae and concluded that there were two valid species, $H$. brachiatus and $H$. tinnunculi. $H$. brachiatus has been reported only from the European kestrel (F. tinnunculus) in Lithuania and its validity requires verification. $H$. tinnunculi is more widespread and has been found in several species of kestrels in North America, Europe, Africa, and Asia (Peirce et al. 1990). It has been reported from crested caracaras in Florida (Foster et al. 1998) and American kestrels (F. sparverius) in Florida (Forrester et al. 1994) and other parts of United States and Canada (Bishop \& Bennett 1992). In addition, $H$. tinnunculi may infect other South American falconids, including caracaras and kestrels, although this is yet to be determined. Both crested caracaras and American kestrels are found on Isla Grande de Chiloé, are known to breed there (JL Morrison, unpublished observations), and may be additional hosts of $H$. tinnunculi in the ecosystem. The fact that only one of the $15 \mathrm{M}$. chimango examined was infected with $H$. tinnunculi may be an indication that the ceratopogonid vectors are present on the island, but in low numbers.

\section{ACKNOWLEDGMENTS}

L Phillips, C Anderson, J Arnett, M Bruscia, L McConnell, S McGehee, J Pinkston, and N Wright assisted in the field and J Armesto, A Iriarte, I Díaz, E Elgueta, C Sabag, and M Willson provided logistical help in Chile. E Greiner verified our identifications of the blood parasites and read and commented on a draft of the manuscript. M Sepúlveda and R Dusek also offered comments on the manuscript.

\section{REFERENCES}

Beltrán E, Pardiñas A 1953. Los protozoarios sanguíeos de les aves méxicanas. Mem Congr Cienc Méx 7: 117-138.

Bishop MA, Bennett GF 1992. Host-parasite catalogue of the avian haematozoa, supplement 1 and bibliography of the avian blood-inhabiting haematozoa, supplement 2. Meml Univ Nfld Occas Pap Biol 15: 1-244.

Boero JJ, Led JE 1971. El parasitismo de la fauna autoctona. V. Los parásitos de las aves argentina. VI. Los parásitos de los ofidios argentinos. VII. Los parásitos de los murcielagos argentinos. Analecta Vet 3: 91-103.

del Hoyo J, Elliott A, Sargatal J 1994. Handbook of the Birds of the World, Vol. 2, New World Vultures to Guineafowl, Lynx Edicions, Barcelona, 638 pp.

Forrester DJ, Telford Jr SR, Foster GW 1994. Blood parasites of raptors in Florida. J Raptor Res 28: 226231.

Foster GW, Morrison JL, Hartless CS, Forrester DJ 1998. Haemoproteus tinnunculi in Crested Caracaras (Caracara plancus audubonii) from southcentral Florida. J Raptor Res 32: 159-162.

Fraga RM, Salvador SA 1986. Biología reproductiva del chimango. Hornero 12: 223-229.

Greiner EC, Kocan AA 1957. Leucocytozoon (Haemosporida: Leucocytozoidae) of the Falconiformes. Can J Zool 55: 761-770.

Greiner EC, Bennett GF, White EM, Coombs RF 1975. Distribution of the avian hematozoa of North America. Can J Zool 53: 1762-1787.

Morrison JL, Phillips LM 2000. Nesting habitat and success of the chimango caracara in southern Chile. Wilson Bull 112: 225-232.

Peirce MA, Bennett GF, Bishop M 1990. The haemoproteids of the avian order Falconiformes. $J$ Nat Hist 24: 1091-1100.

Tendeiro J, Mendes LF 1994. Etudes sur les Colpocephalum (Mallophaga, Menoponidae), parasites des Falconiformes. III - Quelques observations sur le "group polybori" Price \& Beer, avec description de trois especes nouvelles. Garcia Orta Ser Zool 20: 137-140.

White EM, Greiner EC, Bennett GF, Herman CM 1978. Distribution of the hematozoa of Neotropical birds. Rev Biol Trop 26: 43-102.

Yañez JL, Nuñez M, Jaksic F 1982. Food habits and weight of chimango caracaras in Central Chile. Auk 99: 170-171. 